\title{
Fenomena ragam spiritualitas rumah Jawa
}

$59-72$

Satrio Hasto Broto Wibowo

Staf Pengajar Prodi Arsitektur, Fakultas Teknik, Universitas Widya Mataram

Email:satriohb@ymail.com

Abstrak

Budaya spiritualitas masyarakat Jawa terwujud dalam beragam arsitektur rumah Jawa. Spiritualitas dalam ragam rumah Jawa masih banyak yang belum terungkap menjadi ilmu pengetahuan. Penelitian ini bertujuan mengungkap ragam spiritualitas yang mendasari keberadaan ragam rumah Jawa di berbagai wilayah Jawa. Riset lapangan (field research) menjadi metode yang digunakan dalam penelitian ini. Hasil penelitian menunjukkan bahwa spiritualitas dalam rumah Jawa berupa keberadaan sumber spiritualitas di dalam dan di luar rumah Jawa yang berpengaruh terhadap penghuni maupun fisik arsitektural. Sumber spiritual yang berada di dalam rumah berupa Sunan Walisanga, Dewi Sri (mbokde Sri) dan Pasungdari. Keberadaan mereka termnifesatasikan pada ruang (senthong tengah dan pusat rumah) da pada rangka rumah. Sumber spiritual yang berada di luar rumah adalah Ratu Kidul di Laut Selatan dan Dewa-dewi di Keblat. Keberadaan mereka berimplikasi pada arah hadap rumah Jawa menghadap Selatan. Kesimpulan dari penelitian ini adalah bahwa rumah Jawa memiliki ragam spiritualitas yang berbeda-beda dan mendasari terbentuknya arsitektural rumah Jawa.

Kata kunci: rumah Jawa; spiritualitas rumah Jawa; sumber spiritualitas rumah Jawa; implikasi spiritualitas rumah Jawa.

Abstract

The culture of spirituality of the Javanese people is manifested in a variety of Javanese home architecture. Spirituality in a variety of Javanese houses is still much that has not been revealed to be science. This study aims to reveal the variety of spirituality that underlies the existence of a variety of Javanese houses in various regions of Java. Field research became the method used in this study. The results showed that spirituality in the Javanese house was in the form of a source of spirituality inside and outside the Javanese house that affected the occupants as well as the physical architecture. Spiritual sources inside the house are Sunan Walisanga, Dewi Sri (mbokde Sri) and Pasungdari. Their existence is manifested in spaces (the senthong tengah and the center of the house) and in the framework of the house. Spiritual sources outside the home are Ratu Kidul in the South Sea and Gods in Keblat. Their existence has implications for the direction facing Javanese houses facing South. The conclusion of this research is that Javanese houses have different kinds of spirituality and underlie the architectural formation of Javanese houses.

Keyword: Javanese house; the spirituality of Javanese houses; the source of the spirituality of Javanese houses; the implications of the spirituality of Javanese homes.

\section{Pendahuluan}

Masyarakat suku Jawa adalah masyarakat yang sangat lekat dengan nilai-nilai budaya spiritual seperti mistik, mitos, magis (Endraswara, Suwardi, 2006). Melalui perjalanan yang panjang budaya spiritual tersebut tumbuh subur di lingkungan masyarakat Jawa (Herusatoto, Budiono, 1991, h.97). Budaya spiritualitas tersebut pada dasarnya bersumber pada kekuatan yang berada di luar manusia yaitu roh halus, leluhur, dewa, dewi (Koentjaraningrat, 1983, h.342; Herusatoto, Budiono, 1991, h.101). Menurut Endraswara (2006), masyarakat Jawa mempercayai bahwa sumber spiritualitas tersebut dapat membantu mendatangkan kesuksesan, kebahagian, ketentraman, keselamatan, namun dapat terjadi juga sebaliknya hingga kematian.

Budaya spiritualitas masyarakat Jawa yang dipercayainya berimplikasi pada beragam lini kehidupan dengan berbagai wujud aktivitas spiritual. Implikasi budaya spiritualitas juga terjadi pada 
arsitektur rumah Jawa; tujuannya untuk mendukung dan membantu kemudahan kehidupan serta keselamatan masyarakat. Petungan menjadi salah satu bagian spiritualitas dalam rumah Jawa yang sudah banyak diungkap (Kridosasono, 1976; Dakung, dkk, 1985/1986; Prijotomo, Josep dkk., 1995). Dakung dkk (1985/1986) juga mengungkap paham dewa raja untuk rumah raja. Paham spiritualitas lainnya untuk rumah raja belum terlihat terungkap menjadi ilmu pengetahuan. Demikian juga untuk rumah Jawa calon raja, rumah pangeran, rumah bangsawan, dan rakyat terlihat belum banyak diungkap dari sisi spiritualitasnya; dan oleh karenanya perlu diungkap menjadi ilmu pengetahuan.

Salah satu unsur penting dalam spiritualisasi rumah Jawa adalah pelibatan sumber spiritualitas pada rumah Jawa yang senantiasa menjadi hal utama dalam mendasari kehadirannya di wilayah Jawa manapun. Fenomena di diberbagai wilayah di Jawa menunjukkan bahwa sumber spiritualitas, proses spiritualisasi dan implikasi pada rumah Jawa memiliki kesamaan dan sekaligus perbedaan. Dalam ranah ilmu pengetahuan fenomena ragam spiritualitas (perbedaan dan kesamaan) pada rumah Jawa terlihat belum terungkap Pengungkapan beragam spiritualitas rumah Jawa menjadi upaya penting untuk dilakukan guna mengungkap karakteristik keragaman spiritualitas rumah Jawa diberbagai wilayah di tanah Jawa. Diharapkan pengungkapan keragaman spiritualitas rumah Jawa dapat menjadi salah satu sumber ilmu pengetahuan dalam ranah arsitektur rumah Jawa.

\section{Metode}

Metode yang digunakan dalam penelitian ini adalah riset lapangan (field research) atau studi lapangan (field study) (Denzin, Norman, K., et.al, 2009). Metode ini mensyaratkan peneliti sebagai intrumen utama dalam penelitian. Dalam hal ini peneliti harus masuk lapangan untuk melakukan pengumpulan data melalui observasi, wawancara dan studi dokumen. Teknik analisis dalam penelitian ini menggunakan triangulasi data dan triangulasi teori (Denzin, Norman, K., et.al, 2009). Triangulasi data menggunakan sejumlah sumber data dalam penelitian, dan triangulasi teori menggunakan beragam perspekstif untuk mengintepretasikan sekelompok data tunggal.

\section{Hasil dan Pembahasan}

1. Jenis dan fungsi rumah Jawa.

Secara empirik bila dilihat dari penghuninya rumah Jawa terdiri dari empat jenis yaitu rumah raja, rumah pangeran putra mahkota, rumah pangeran, rumah bangsawan (kerabat raja), rumah pejabat kerajaan, dan rumah rakyat (perdesaan dan perkampungan). Masing-masing jenis rumah 
memiliki karakteristik bentuk atau wujud bangunan, keruangan, kelengkapan bangunan yang berbeda-beda satu dengan yang lainnya.

Dari hasil pengamatan dan didukung oleh Tri Yuniastuti dkk (2008), jenis rumah raja merupakan rumah yang memiliki klasifikasi tertinggi, baik dari sisi keruangan, bentuk arsitektural, dimensi luasan maupun kelengkapan bangunannya. Terdapat dua fungsi utama rumah raja yaitu untuk tempat tinggal keluarga kerajaan dan sebagai tempat pusat pemerintahan kerajaan. Atas dasar itulah maka rumah raja memiliki banyak bangunan dengan fungsi dan jenis bangunan Jawa yang beragam serta dilengkapan dengan ragam hias bangunan yang penuh makna.

Jenis kedua dari rumah Jawa adalah rumah pangeran atau dalem pangeran. Fungsi dalem pangeran adalah sebagai tempat tinggal pangeran yaitu anak raja yang sudah dewasa beserta keluarganya. Di Yogyakarta setidaknya terdapat lebih dari 40 buah rumah pangeran yang tersebar di sekitar Kraton Yogyakarta. Terdapat dua jenis dalem pangeran yaitu dalem pangeran calon raja dan rumah pangeran biasa. Rumah pangeran calon raja hanya didapati satu dalem yaitu dalem Kadospaten (dalem Mangkubumen). Dalem ini adalah hunian Pangeran Adipati Anom calon Sultan Hamengku Buwono ke VII. Selain dalem calon raja semuanya adalah dalem pangeran biasa yang dihuni oleh anak raja maupun saudara-saudara (adik dan kakak) raja.

Jenis ketiga adalah rumah bangsawan atau kerabat kerajaan, berfungsi sebagai tempat tinggal bagi bangsawan (kerabat Keraton di bawah pangeran). Karakteristik rumah bangsawan umumnya setingkat lebih sederhana dari rumah pangeran pada umumnya. Di Yogyakarta, keberadaannya di sekitar kraton Yogyakarta.

Jenis rumah Jawa keempat adalah rumah pejabat kerajaan seperti patih (wakil raja), panglima perang kerajaan, rumah bupati, tumenggung, rumah abdi dalem hingga lurah). Rumah pejabat kerajaan yang masih dapat eksis adalah rumah patih di Kepatihan Yogyakarta, rumah bupati di Imogiri, rumah abdi dalem dan rumah Lurah di berbagai perdesaan).

Jenis rumah Jawa kelima adalah rumah rakyat di perkampungan atau perdesaan. Fungsi rumah rumah rakyat adalah sebagai tempat tinggal (hunian) keluarga. Keberadaannya tersebar di dalam dan di luar kota raja.

\section{Tipe bangunan.}

Ditinjau dari bentuk atapnya Arsitektur rumah Jawa terdiri dari empat jenis yaitu tajug/masjid, joglo, limasan, kampung (Mangoendarmo, 1906; Ngabei Ranggasutrasna dkk, 2008); dan Dakung dkk (1985/1986) serta Ismunandar (1993) menambahkan panggang pe sebagai jenis bangunan Jawa yang kelima.

Dari hasil pengamatan terhadap rumah raja, rumah pangeran, rumah bangsawan (kerabat raja), rumah pejabat kerajaan, dan rumah rakyat diketahui menggunakan kombinasi tipe-tipe 
bangunann Jawa tajug, joglo, limasan, kampung dan panggang pe. Tipe-tipe tersebut dikombinasikan menjadi satu kesatuan rumah Jawa. Rumah Jawa yang menggunakan empat tipe bangunan berdasarkan atapnya adalah rumah raja dan dalem pangeran calon raja. Masjid menggunakan tipe tajug, pendapa dan pringgitan menggunan tipe joglo lambang gantung, dalem prabayeksa menggunakan tipe limasan lambang gantung dan bangunan pendukung bertipe limasan dengan berbagai varian.

Rumah pejabat kerajaan dan dalem pangeran biasa serta pangeran umumnya menggunakan kombinasi tipe joglo-limasan-kampung. Untuk rumah rakyat umumnya menggunakan tipe limasan-limasan, limasan-kampung dan limasan (satu limasan) serta kampung (satu kampung).

3. Spiritualisasi pada rumah raja.

Inti rumah raja khususnya kerajaan Ngayogyakarta Hadiningrat berada di tengah-tengah kraton yang meliputi bangsal kencana, prabayeksa, gedhong jene dan bangsal prabayeksa. Inti rumah raja tersebut menggunakan konsep dewa raja (Dakung, dkk, 1985/1986; Kridosasono, 1976). Menurut Dakung, konsep dewa raja merupakan kepercayaan masyarakat kepada raja sebagai titisan dari Sang Hyang Dewa. Keberadasan dewa-dewi berada di keblat (Kridosasono, 1976). Sang Hyang Maha Dewa-Dewi bertahta di keblat Timur; keblat Barat ditempati oleh Batahara Komajaya dan Bathara Komaratih; keblat Utara ditempati oleh Sang Hyang Wisnu yaitu sebagai dewa penolong yang arif dan bijaksana.; dan keblat Selatan ditempati oleh Bethara Sambu-Bethari Swatnyana. Implementasi dari paham dewa raja ini adalah berupa penggubahan arah hadap atau orientasi rumah inti raja menghadap arah Timur (Gambar 1). Arah Utara, Selatan dan Barat sebagai tempat dewa-dewi yang lain tidak diimplementasikan dalam rumah raja.

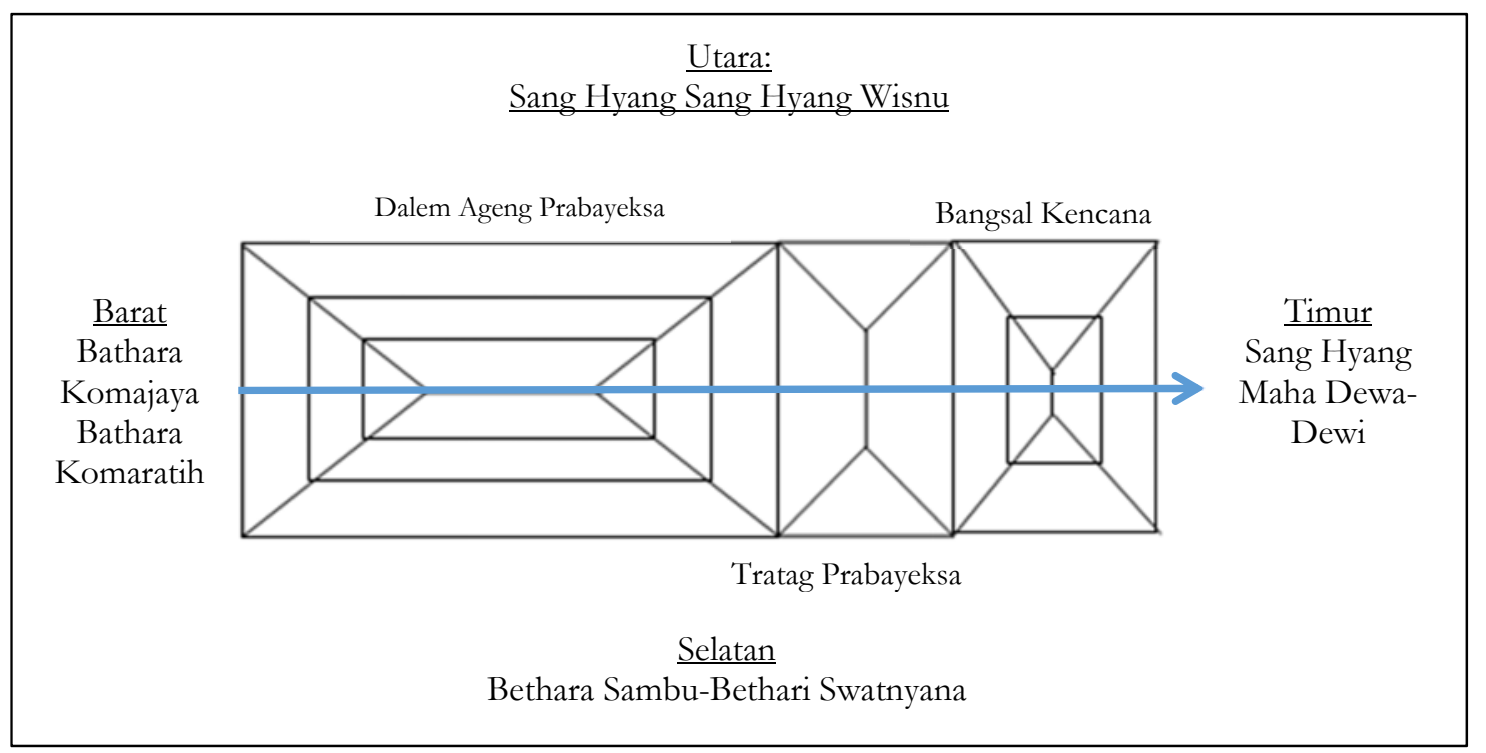

Gambar 1. Orientasi Inti Rumah Raja Arah Timur Dengan Paham Dewa Raja 
Orientasi rumah raja pada skala keseluruhan/makro (bukan skala inti rumah raja) menggunakan nilai spiritual Ketuhanan (Gambar 2). Spiritual Ketuhanan diimplemenatasikan dalam arah hadap kraton arah Utara dan Selatan. Arah Utara merupakan arah Ketuhanan. Arah ini ditunjukkan dengan keberadaan tugu pal puth sebagai simbol bersatunya Kawula dan Gusti, bersatu hamba dan Tuhannya (Brongtodiningrat, KPH, h. 20-21, tak bertahun). Dasar dari orientasi ini adalah ketika Sang Raja bertahta di bangsal manguntur tangkil bersemadi menyiapkan diri untuk bertemu Tuhan Yang Maha Kuasa yang disimbolkan dengan keberadaan tugu di ujung Utara sebagai tempat Alif Mutakalliman Wachid, badan, Ilafi

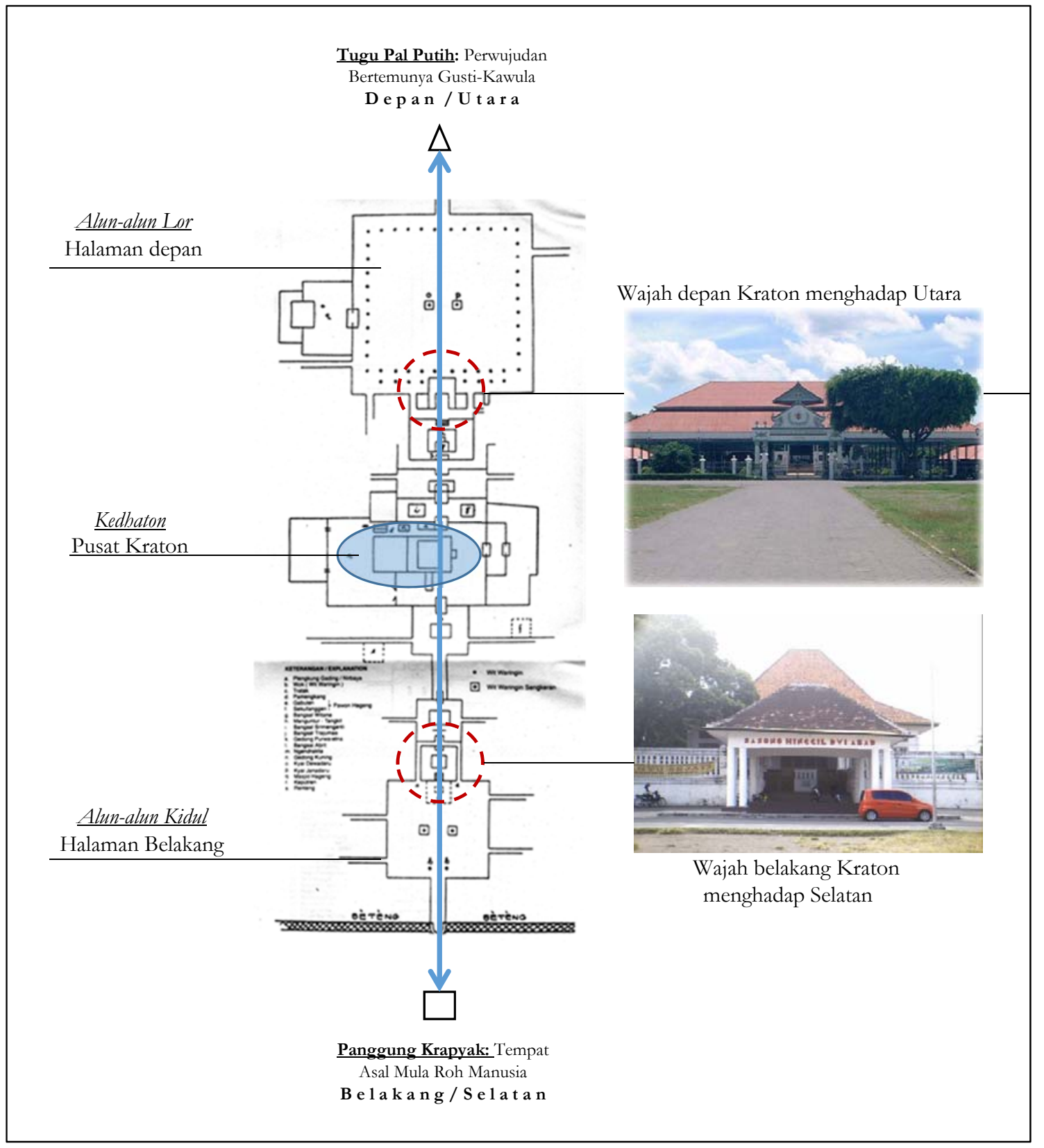

Gambar 2. Orientasi Rumah Raja Skala Makro Dengan Konsep Ketuhanan 
Pada gambar 2 di atas ditunjukkan juga bahwa arah Selatan sebagai orientasi belakang kerajaan pada dasarnya berkeblat pada panggung krapyak. Secara filosofis dan spiritual panggung Krapayak menyimbolkan gambaran tempat asal roh-roh (Brongtodiningrat, KPH, h.13, tak bertahun). Roh-roh tersebut hadir (mijil) menjadi manusia dan bergerak menuju arah Utara untuk tumbuh berkembang menjadi manungsa utama (raja) dan bersatu / manunggal dengan Tuhan di sebelah Utara.

KPH. Brongtodiningrat juga mengungkapkan bahwa untuk kembali pada Tuhan maka roh manusia akan masuk ke area terang benderang yang disimbolkan sebagai dalem ageng prabayeksa. Di dalam dalem ageng inilah roh manusia akan dituntun menuju swarga yang disimbolkan dalam wujud gedhong jene. (Gambar 3)

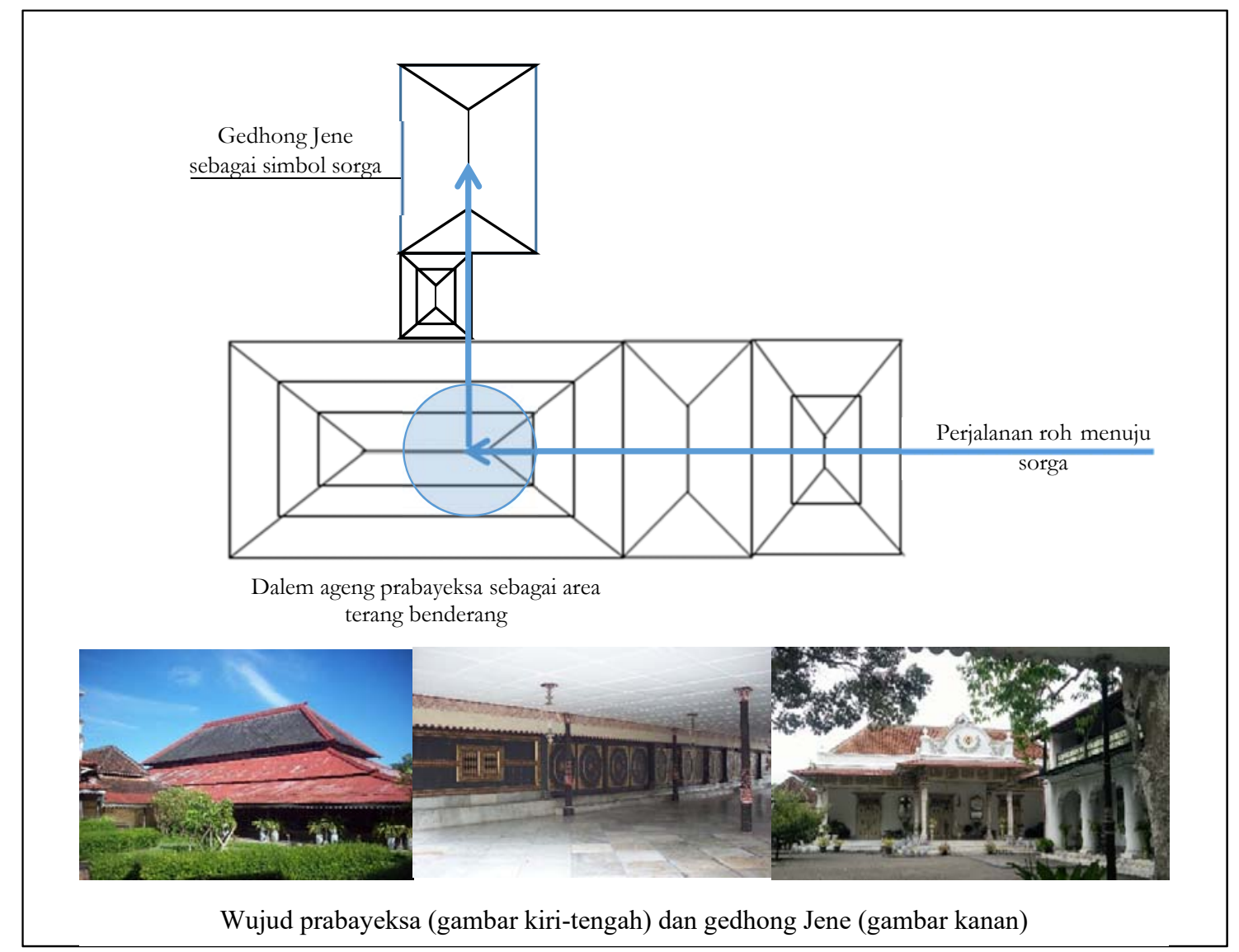

Gambar 3. Perjalanan roh manusia kembali pada Tuhan dalam spiritualitas Ketuhanan

Selain konsep spiritual yang berupa kedewaan dan Ketuhanan, rumah raja juga menggunakan konsep spiritual kejawaan. Konsep kejawaan ini berupa keberadaan penguasa spiritual (roh) yang manggon (menempati) dalem prabayeksa. Penguasa spiritual tersebut berkuasa atas kraton dan senantiasa diuri-uri oleh penghuni kraton melalui para abdi dalemnya. Oleh Mangunwijaya (1988) penguasa spiritual tersebut dinamai sebagai "Sang Tani”. Implementasi 
dalam hal ini adalah bahwa pemilik dalem yaitu raja tidak tinggal di dalem prabayeksa namun di bangunan lainnya yaitu di gedhong Jene. Dalam catatan sejarah lisan, dalem prabayeksa hanya digunakan untuk tempat tinggal Sultan Hamengkubuwono yang pertama. Sultan-sultan setelahnya tidak lagi menempati dalem ageng prabayeksa

4. Spiritualisasi pada dalem pangeran calon raja, Pangeran dan Bangsawan

Seperti halnya pada dalem ageng prabayeksa di kraton Ngayogyakarta Hadiningrat, spiritualitas dalem pangeran calon raja yaitu dalem Kadospaten (dalem Mangkubumen) terletak di dalam dalem prabayeksa (Gambar 4). Di dalem prabayeksa inilah penguasa spiritual manggon (menempati) dan berkuasa atas seluruh penghuni dalem. Berbeda dengan rumah raja dan dalem pangeran calon raja, spiritualisasi dalem pangeran dan bangsawan terletak pada senthong tengah (gambar 4) Senthong tengah terletak di bagian dalem (belakang) diapit oleh dua senthong yaitu senthong kiwa di bagian kiri dan senthong tengen di samping kanan. Di dalam senthong tengah inilah bersemayam Dewi Sri; dan di tempat inilah penghuni dalem melakukan semadi dan komunikasi dengan para leluhurnya (Gambar 5).

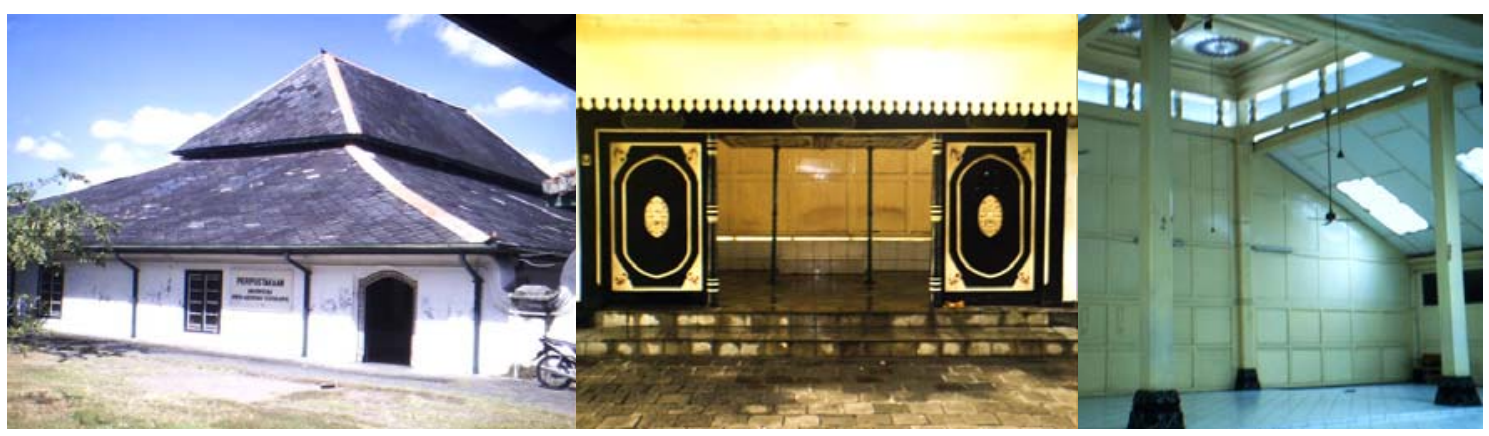

Gambar 4. Dalem Prabayeksa di Dalem Mangkubumen

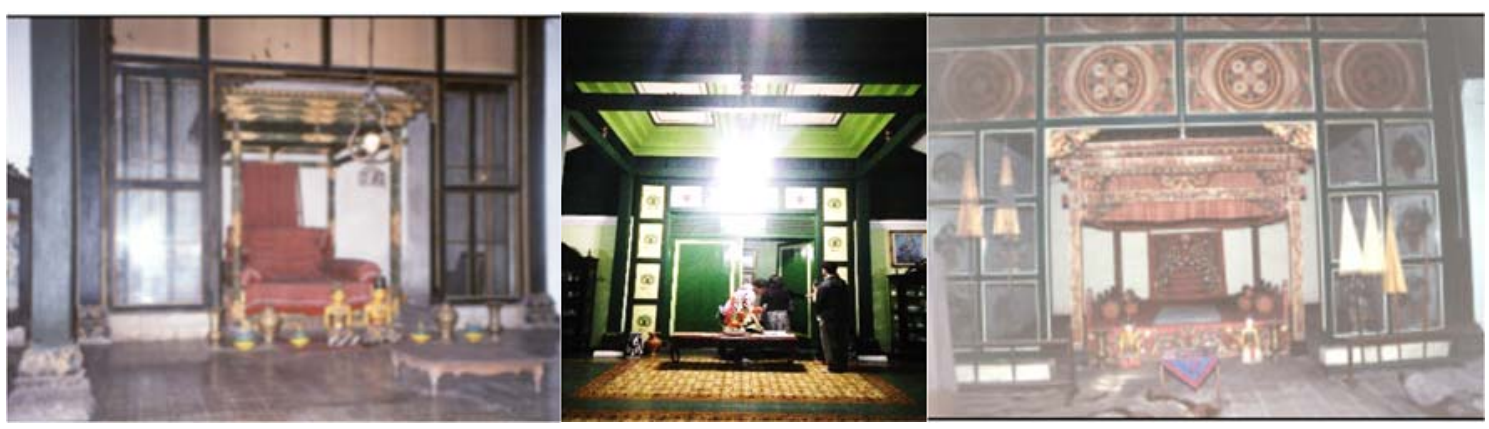

Senthong Tengah Dalem Pakuningratan (gambar kiri); Senthong Tengah Dalem Benawan (gambar tengah); Senhong Tengah Dalem Notoprajan (gambar kanan)

Gambar 5. Senthong Tengah di Dalem Pangeran

Sumber: Widyatsari (2002) dan Dokumentasi 
5. Spiritualisasi pada rumah rakyat di perkampungan.

Rumah rakyat perkampungan diambil sampel dari wilayah Kota Gede, Yogyakarta. Tjahjono, Gunawan (1990) menyatakan dalam disertasinya bahwa senthong tengah merupakan tempat manggon-nya Dewi Sri sebagai dewi pemberi kehidupan; dan oleh senthong tengah menjadi ruang yang sakral dan disakralkan (Gambar 6). Di lain sisi disebutkan bahwa sebagai pusat spiritualisasinya adalah pendapa yang berada di bagian terdepan. Tjahjono menyatakan bahwa pusat spiritualitas merujuk kepada fungsinya untuk melakukan ritual pembakaran dupa untuk Dewi Sri.

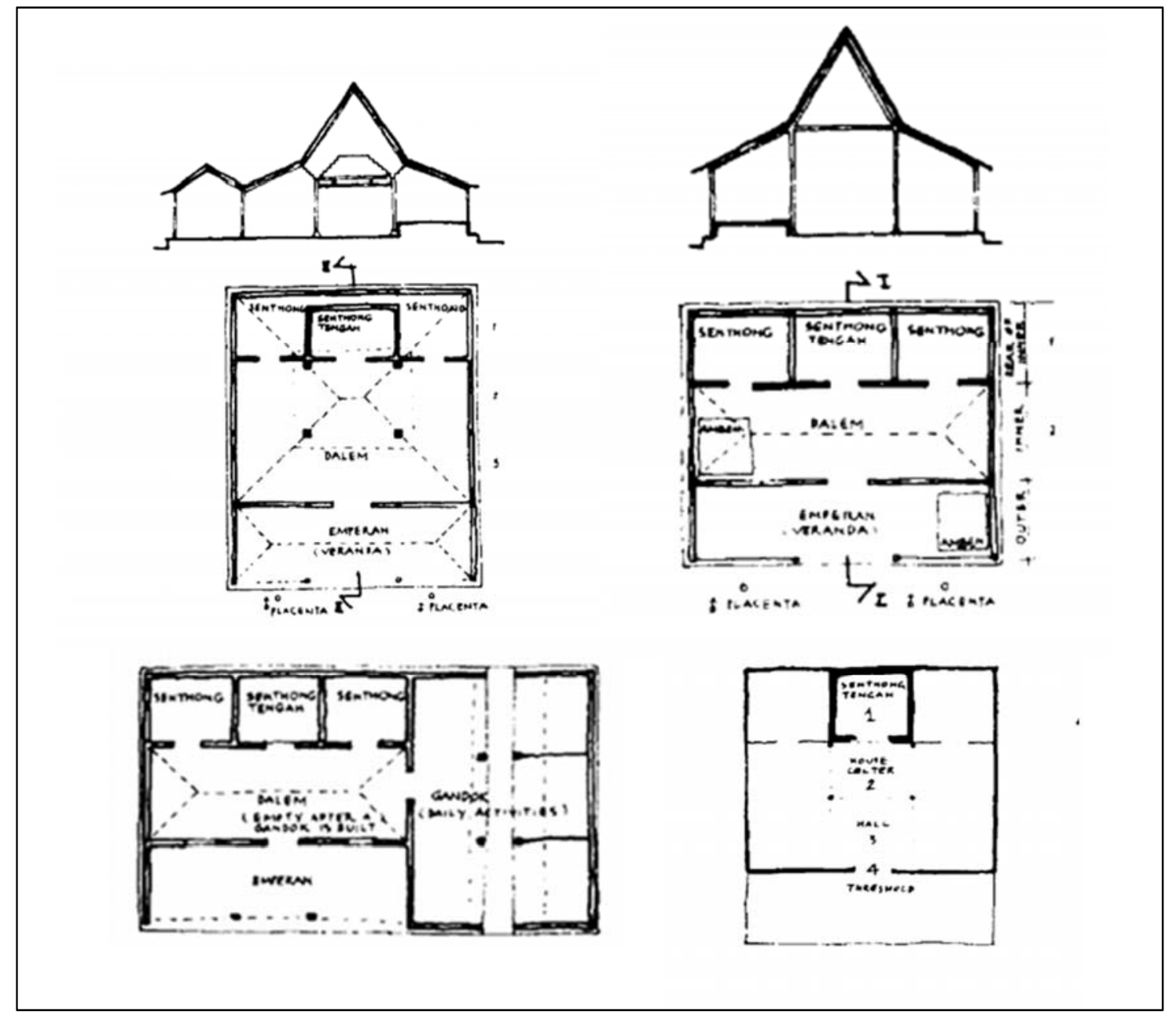

Gambar 6. Senthong Tengah di Rumah Jawa Kota Gede, Yogyakarta Sumber: Tjahjono, Gunawan (1990)

6. Spiritualisasi pada rumah perdesaan

Beberapa rumah Jawa perdesaan di seputar Yogyakarta, Purworejo dan Pacitan memiliki sumber spiritual yang berbeda-beda. Di desa Purwodadi, Tepus, Gunungkidul sumber spiritualnya 
berada di keblat (arah mata angin) (Wibowo, Satrio, 2013) (Gambar 7). Sri (mbokde Sri) adalah sumber makanan berada di Kidul (Selatan); Wiwitan adalah sumber spiritual di sisi Timur; Wabyu, sumber spiritual di sisi Kulon (Barat) dan Sengkala adalah sumber spiritual yang wengkoni (menguasai) keblat Lor (Utara). Kepercayaan terhadap sumber spiritual tersebut diwujudkan dalam arah hadap bangunan menghadap Selatan yaitu menghadap mbokde Sri sebagai sumber makanan; atas adalah Bapa Angksa dan bawah adalah Naga Pertala (ibu bumi). Spiritualisasi lainnya adalah sumber spiritual yang terkait dengan karibawan (kewibawaan) rumah. Menurut Wibowo (2013) sumber spiritual karibawan (kewibawaan) berada juga di lima keblat yaitu keblat tengah diwengkoni oleh Pasungdari, Lor Wetan (Timur Laut) diwengkoni Nogorojo, Begawan Respati wengkoni keblat Lor Kulon (Barat Laut), Dewi Shinta wengkoni keblat Kidul Kulon (Barat Daya) dan Bambang wengkoni Kidul Wetan (Tenggara). Penguasaan rumah Jawa di desa Purwodadi oleh sumber spiritual tersebut menjadikan rumah Jawa menjadi berwibawa.

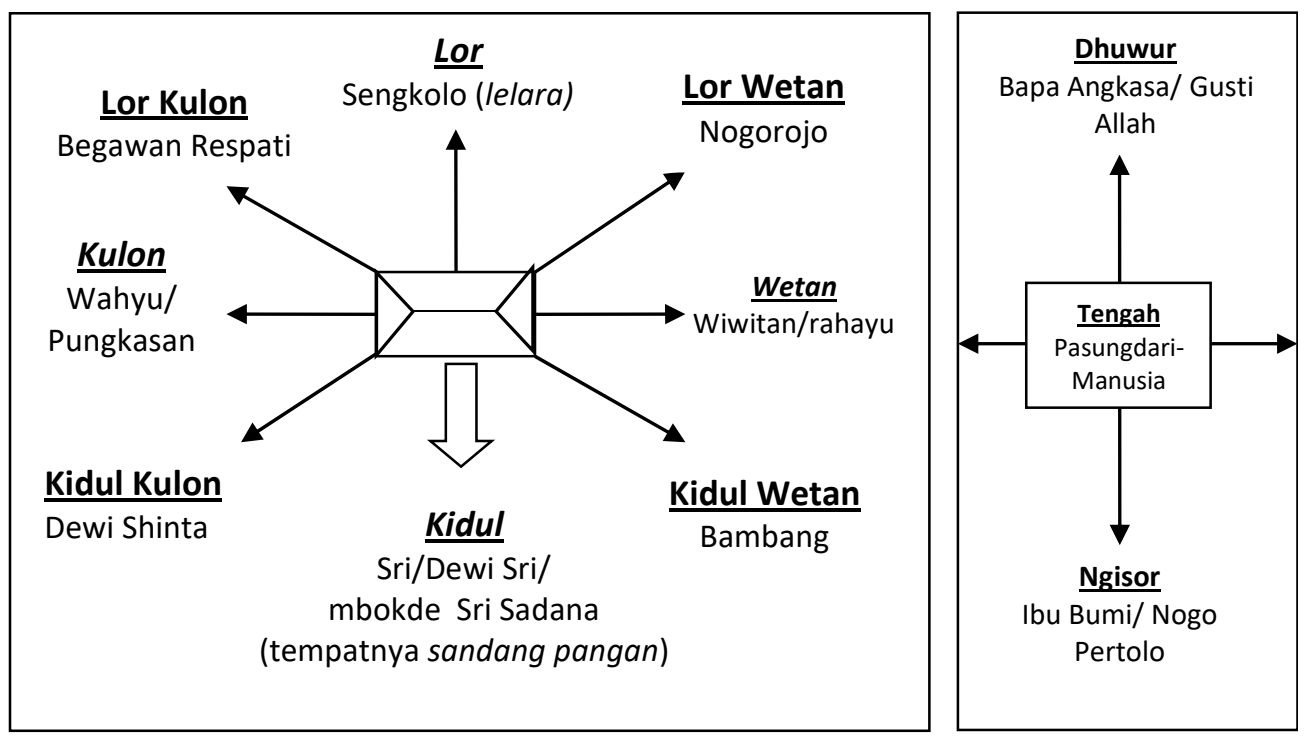

Gambar 7. Spiritualisasi Rumah Jawa di Desa Purwodadi, Tepus, Gunungkidul

Berbeda dengan rumah Jawa di desa Purwodadi, Tepus, Gunungkidul, di wilayah Urut Sewu, kecamatan Grabag, Purworejo, Jawa Tengah spiritualitas pada rumah Jawa yaitu omah dudur bersumber pada Wahyu (Wibowo, Satrio 2017). Wahyu sebagai sumber spiritualitas merupakan perwujudan dari tiga pribadi yaitu Sunan Walisanga dan Ratu Kidul. Sunan Wali sanga manggon di omah dudur pada rangka rumah yaitu di saka papat, saka keblat njaba, dhadha wesi dan sunan (nok) (Gambar 8). Keberadaan sumber spiritual tersebut memberikan karibawan (berwibawa), keslametan (keselamatan), adem ayem (kebahagian) dan cekap sandang pangan (berkecukupan). Terhadap bangunan, sumber spiritualitas memberikan pengaruh yang berwujud kawibawaan, bangunan menjadi hidup, dan ganteng (estetis). 


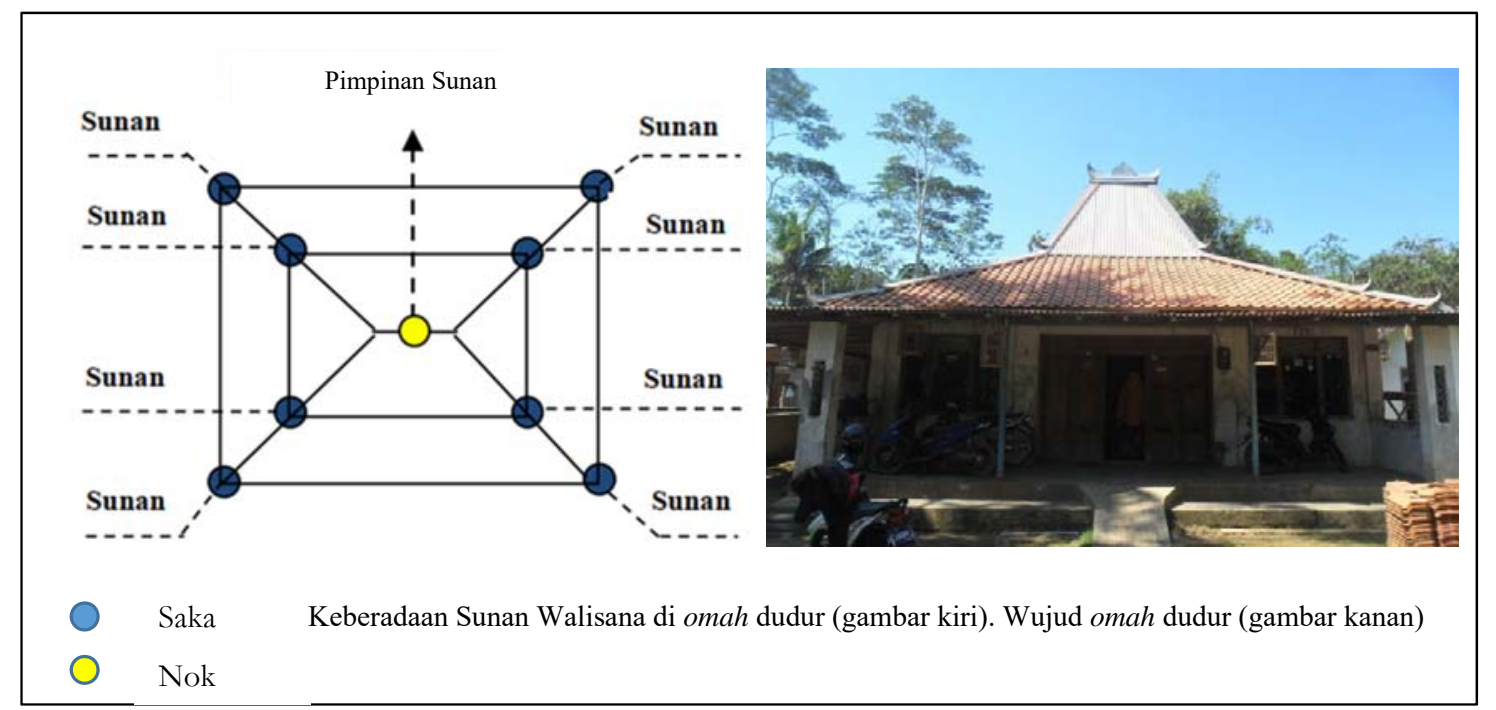

Gambar 8. Sumber spiritualitas omah dudur di wilayah Urut Sewu, Grabag, Purworejo

Pribadi spiritual ketiga adalah ratu Kidul. Ratu Kidul tidak manggon di omah dudur namun di samudra Indonesia. Keberadaannya menjadi sumber kehidupan secara fisik dan rohani. Secara fisik, laut selatan sebagai sumber makanan dan secara rohani laut selatan sebagai istana ratu Kidul merupakan sorga bagi masyarakat Urut Sewu. Atas dasar itulah maka omah dudur di wilayah Urut Sewu ini berorientasi ke Selatan yaitu ke arah keberadaan Ratu Kidul.

Di wilayah Sleman khususnya Kalasan, Godean dan pantai Selatan Bantul, jejak senthong tengah sebagai tempat bersemayamnya Dewi Sri masih terlihat (gambar 9). Selain itu arah hadap bangunan ke Selatan juga masih terlihat sebagai perwujudan penghormatan kepada Ratu Kidul. Di wilayah Kecamatan Donorojo, Pacitan Jawa Timur, sumber spiritual berada di penumun (nok) (Yuniastuti, Tri, dkk., 2016). Pada penuwun itulah terdapat nilai spiritual yang terbentuk secara sinkretisme antara kepercayaan kejawen dengan Islam khususnya terkait dengan Sunan Walisanga.

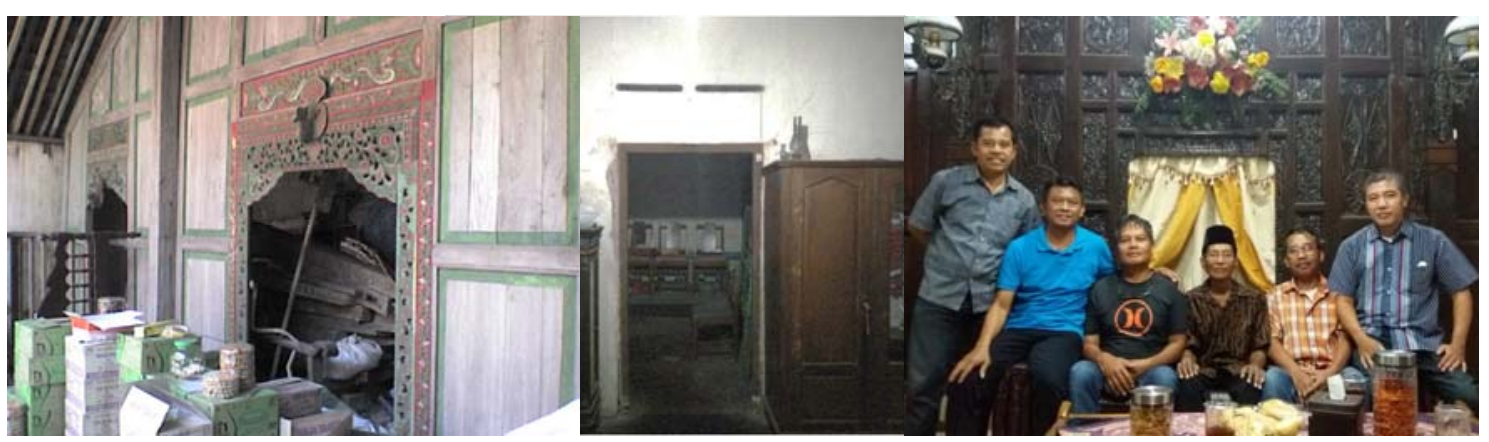

Senthong tengah di Bantul (gambar kiri), di Godean (gambar tengah) dan di Kalasan (gambar kanan)

Gambar 9. Senthong tengah di rumah Jawa Perdesaan 


\section{Kesimpulan dan Masukan.}

1. Kesimpulan

Berdasarkan pembahasan yang telah dijelaskan di atas maka kesimpulan yang dapat disampaikan adalah seperti dikemukakan di bawah ini.

1.1. Rumah Jawa memiliki sumber dan implikasi spiritualitas yang beragam. Setidaknya terdapat lima sumber spiritualitas yaitu Ketuhanan, Keagamaan (agama Islam/rukun Islam), Sunan Walisanga, Dewa dan Dewi, dan kejawen. Implikasi spiritualitas pada rumah Jawa adalah berwujud senthong tengah, rangka rumah, ruang tengah, pendapa, keblat serta arah hadap bangunan. Dalam pemanfaatannya terhadap sumber spiritualitas, rumah Jawa menghadirkan satu, dua hingga tiga sumber spiritualitas.

1.2. Keberadaan sumber spiritual yang manggon (menempati) di dalam Rumah Jawa membentuk rumah Jawa sebagai rumah spiritual. Di dalam rumah Jawa tersebut terbentuk hubungan komunikasi antara manusia sebagai penghuni rumah dengan sumber spiritualitas melalui sikap mundi-mundi (menghormati), nguri-uri (menjaga), dan berkomunikasi melalui ritual tertentu maupun semedi dengan segala uborampenya.

\section{Masukan}

Masukan-masukan untuk penelitian berikut adalah terkait dengan pemanfaatan banyaknya sumber spiritualitas di rumah raja, kraton Yogyakarta. Kiranya hal tersebut dapat digali untuk mendapatkan temuan yang lebih lengkap dan detail melalui metode fenomenologi. Selain itu disarankan untuk meneliti spiritualitas padas rumah perkampungan dan perdesaan lainnya untuk melengkapi temuan-temuan spiritualitas rumah Jawa.

\section{Daftar Pustaka}

Brongtodiningrat, KPH. (tak bertahun). Arti Kraton Yogyakarta. Museum Kraton Yogyakarta. Yogyakarta

Dakung, S. dkk. 1985/1986. Arsitektur Tradisional Daerah Istimewa Yogyakarta, Depertemen Pendidikan dan Kebudayaan Proyek Inventarisasi dan Dokumentasi Kebudayaan Daerah.

Djono;, Utomo, Tri Prasetyo; Subiyantoro, Slamet. 2012. Nilai Kearifan Lokal Rumah Tradisional Jawa. Jurnal Humaniora Vol.24. No.3. hal. 269-278.

Endraswara, Suwardi. 2006. Mistik Kejawen, Sinkretisme, Simbolisme dan Sufisme dalam Budaya Spriritual Jawa, Yogyakarta

Herusatoto, Budiono. 1991. Simbolisme dalam Budaya Jawa, Hanindita, Yogyakarta. 
Ismunandar, R.K. 1993. Joglo Arsitektur Rumah Tradisional Jawa. Dahara Prize, Semarang.

Jenesick, Valerie J. 2009. Tarian Desain Penelitian Kualitatif: Metafora, Metodolatri, dan Makna Dalam Denzin, Norman.K. dan Lincoln, Yvonna.S. (ed). Handbook Of Quality Research. Pustaka Pelajar. Yogyakarta.

Kodiran. 1983. Kebudayaan Jawa Dalam Koentjaraningrat (ed.). Manusia Dan Kebudayaan Di Indonesia. Djambatan.

Kridosasono, Slamet (Penyalin). 1976. Kawruh Kalang Ilmu Pertukangan Kayu/Membuat Rumah Kayu. Surakarta.

Mangoendarmo (Penyalin). 1906. Serat Kawruh Griya. Panti Budaya. Yogyakarta.

Mangunwijaya, Y.B.1988. Wastu Citra, Pengantar ke Ilmu Budaya Bentuk Arsitektur Sendi-sendi Filsafatnya Beserta Contoh-contoh Praktisnya. PT. Gramedia, Jakarta.

Prijotomo, Josep. dan Rachmawati, Murni. 1995. Petungan: Sistem Ukuran Dalam Arsitektur Jawa. Gadjah Mada University Press, Yogyakarta.

Ranggasutrasna, Ngabei, Dkk. 2008. Centini Tambangraras Amongraga, Jilid III. Balai Pustaka, Jakarta.

Tjahyono, Gunawan. 1990. Cosmos, Center, and Duality In Javanese Architectural Tradition: The Symbolic Dimensions of House Shapes In Kota Gede and Surroundings. Dissertation. U.M.I. Ann Arbor.

Wibowo, Satrio. 2013. Arsitektur Omah Bunder di Desa Purwodadi, Kecamatan Tepus, Kabupaten Gunungkidul. Thesis. Universitas Gadjah Mada.

Wibowo, Satrio. 2017. Revealing Trancendental Meaning Of Omab Dudur Architecture in Urut Sewu, Grabag, Purworejo, Central Java, Indonesia. LivaS - International Journal of Livable Space, Vol. 02, No. 1.

Widyatsari, Lestari. (2002). Tata Ruang Rumah Bangsawan Yogyakarta. Jurnal Dimensi Teknik Arsitektur. Volume 30, No. 2. Universitas Petra Surabaya

Yuniastuti, Tri; Wibowo, Satrio; Sukirman. 2016. Rumah Tradisional Jawa: Pacitan. Lintang Pustaka Utama. Yogyakarta.

Yuniastuti, Tri; Wibowo, Satrio. 2008. Perubahan Bentuk Bangunan Tradisional Jawa "Bangsal Alit Kilen” Pada Dalem Mangkubumen Yogyakarta. 